\title{
Modelling the risk of mortality of Corbicula fluminea (Müller, 1774) (Bivalvia: Corbiculidae) exposed to different turbidity conditions
}

\author{
Avelar, WEP. ${ }^{a *}$, Neves, $F^{a}{ }^{a}$ and Lavrador, MAS. ${ }^{b}$

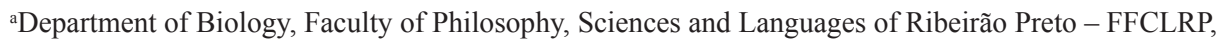 \\ University of São Paulo - USP, Brazil, Av. Bandeirantes, 3.900, Monte Alegre, CEP 14040-901, Ribeirão Preto, SP, Brazil \\ ${ }^{b}$ Department of Physics and Chemistry, Faculty of Pharmaceutical Sciences of Ribeirão Preto - FCFRP, \\ University of São Paulo - USP, Av. Bandeirantes, 3.900, Monte Alegre, CEP 14040-901, Ribeirão Preto, SP, Brazil \\ *e-mail: waavelar@ffclrp.usp.br
}

Received October 2, 2012 - Accepted March 7, 2013 - Distributed May 31, 2014

(With 3 figures)

\begin{abstract}
The provision of sediment in rivers, due to erosion processes that occur in the environment, consists of a major source of pollution and alteration of the physicochemical conditions of water resources. In addition, the increase in water turbidity may cause siltation, dramatically impacting aquatic communities. Specifically considering the bivalve Corbicula fluminea (Müller, 1774), the aim of this study was to analyse the effect of exposure to different turbidity conditions of sediments, as a risk factor for the animals. For this purpose, a docking device was designed to ensure water circulation in a closed system and to maintain the desired levels of turbidity. Although C. fluminea can generally tolerate environmental changes in aquatic systems, an intolerance to high turbidity levels was experimentally observed, expressed by the mortality rate of the animals when exposed to conditions above 150 nephelometric turbidity units (NTU). This value was similar to the one recorded at study sites in the rivers Pardo (Serrana-SP-Brazil) and Mogi Guaçu (Porto Ferreira-SP-Brazil) during the rainy season. Using a logistic regression model, the experimental results were analysed and the observed mortality rates indicate that the exposure of the animals to turbidity levels above 150 nephelometric turbidity units (NTU), for periods longer than 120 hours, may be considered a probable cause of mortality for the species.
\end{abstract}

Keywords: biodiversity, bivalve, erosion, watershed, logistic regression.

\section{Modelagem do risco de mortalidade de Corbicula fluminea (Müller, 1774) (Bivalvia: Corbiculidae) exposta a diferentes condições de turbidez}

\section{Resumo}

A disponibilização de sedimentos nos cursos d'água, em função dos processos erosivos que ocorrem no entorno, constitui-se e uma das principais fontes de poluição e alteração das condições físico-químicas dos recursos hídricos. Além disso, o aumento da turbidez da água pode causar assoreamento, impactando drasticamente as comunidades aquáticas. Especificamente para o bivalve Corbicula fluminea (MÜLLER, 1774), este estudo teve por objetivo analisar o efeito da exposição a diferentes condições de turbidez, como fator de risco para os animals. Para esta finalidade, um dispositivo de acoplamento foi concebido para assegurar a circulação da água, em um sistema fechado mantendo os níveis desejados de turbidez. Embora $C$. fluminea possa tolerar mudanças ambientais em sistemas aquáticos, foi observadao experimentalmente, uma intolerância a turbidez acima de 150 unidades nefelométricas de turbidez (NTU), um valor próximo ao registrado em pontos de estudo nos rios Pardo (Serrana-SP-Brasil) e Mogi Guaçu (Porto FerreiraSP-Brasil) durante a estação chuvosa. Por intermédio da utilização de um modelo de regressão logística, os resultados experimentais foram analisados. As taxas de mortalidade observadas indicam ser a exposição dos animais a níveis de turbidez acima desse limite e por períodos mais longos do que 120 horas uma provável causa de mortalidade desta espécie.

Palavras-chave: biodiversidade, bivalve, erosão, bacia hidrográfica, regressão logística.

\section{Introduction}

Corbicula fluminea (Müller, 1774) (Bivalvia: Corbiculidae) is an exotic species which was introduced in South America in 1970 (Ituarte, 1981), probably by means of ballast water from ships entering the Rio da Prata estuary
(Mansur et al., 2004). This species has been the subject of a great deal of research due to its capacity to spread over large areas and become an important competitor with native species of freshwater bivalves, potentially causing 
ecological imbalance. High densities of this bivalve (over 200 individuals $/ \mathrm{m}^{2}$ ) have been considered potentially harmful, both for channelling water and for hydroelectric power (Mansur and Garces, 1988).

Freshwater bivalves generally live buried in muddy or sandy riverbeds, at depths which vary according to the size of the specimens. They feed primarily on phytoplankton. C. fluminea does not show any preference for a particular sediment texture (Belanger et al., 1985), substrate, or vegetation cover, showing a high level of resistance to changes in physical-chemical parameters of water temperature and salinity (Kat, 1982).

However, while much of the literature involves scientific anatomy and functional morphology of bivalves (Hebling, 1976; Avelar and Santos, 1991; Avelar, 1993; Simone, 1994, 1997; Avelar and Cunha, 2009) or addresses reproductive aspects (Peredo and Parada, 1986; Avelar et al., 1991; Avelar and Mendonça, 1998; Mansur and Campos-Velho, 2000), there is still no scientific evidence in the literature that addresses the influence of suspended sediments on the mortality rates of bivalve populations.

At a watershed level, the rainy season increases the river's flow measurement and the velocity of its current, which is associated with the re-suspension of sediment particles (Christofoletti, 1981) and the transportation of solutes caused by erosion of the river margins (Neves et al., 2006), thereby increasing the turbidity of the water. Several studies have shown the influence of turbidity and suspended sediments on the life cycle of aquatic animals (Henley et al., 2000; Poole and Downing, 2004; Österling et al., 2010), specially for suspended sediment which is the main concern of this study.

Despite the numerous and often interrelated factors causing the decline of bivalve populations (Andersen, 2002), no scientific study has addressed the causes of the seasonal decline of $C$. fluminea populations.

Thus, the objective of this study was to analyse the mortality of $C$. Aluminea in terms of the turbidity of the water under laboratory conditions and to establish a functional relationship amongst the results by means of a model based on the logistic regression model. This model has already been successfully used to deal with similar problems (Venables and Dichmont, 2004; Liao et al., 2007), and it is a promising tool to try to explain the relationship between the percentage of molluscs deaths and the water turbidity levels.

\section{Material and Methods}

\subsection{Location}

The study was conducted in two areas located in micro watersheds in the State of São Paulo, Brazil with the coordinates $\left(21^{\circ} 10^{\prime} 44,9^{\prime \prime} \mathrm{S}\right.$ and $\left.47^{\circ} 34^{\prime} 30,5^{\prime \prime} \mathrm{W}\right)$ for the Pardo River and (21 ${ }^{\circ} 50^{\prime} 36,1^{\prime \prime} \mathrm{S}$ and $\left.47^{\circ} 29^{\prime} 44,5^{\prime \prime} \mathrm{W}\right)$ for the Mogi Guaçu River.

The following abiotic components were monthly monitored, from October 2007 to October 2008: dissolved oxygen (in percentage) measured using a YSI52 Oximeter; turbidity, analysed with the aid of a portable $2100 \mathrm{P}$ Turbidimeter; temperature (in Celsius); electrical conductivity (in $\mu \mathrm{S}$ ) obtained by using a YSI30 conductivity meter

\subsection{Specimen collection and acclimation}

At each study site, 200 C. fluminea, with resembling size and weight, were collected from the sediment at the bottom of both rivers using hands or feet.

The specimens collected at each study location were transported to the laboratory in coolers and packed separately in batches, which were kept in asbestos boxes measuring $70 \times 70 \times 70 \mathrm{~cm}$. These containers allowed for the open circulation of mine water and were acclimatised to a temperature of $27^{\circ} \mathrm{C}$ for 72 hours. This temperature represents an average summer temperature for both the Mogi Guaçu and Pardo Rivers.

During both the acclimation and experimental phases, the bivalves were fed "ad libitum" with microalgae, mainly chlorella collected at the study sites and cultured in the laboratory.

\subsection{Experiment to determine the risk of mortality in C. fluminea}

The experiment analysed the effect of turbidity and any possible influence of the watersheds chosen for the study, on the mortality of $C$. fluminea.

A docking device was designed which consisted of mounting a water pump to a hydraulic system (Figure 1) in order to ensure water circulation in a closed system and to maintain the desired levels of turbidity constant in all the 10 tanks, as described below.
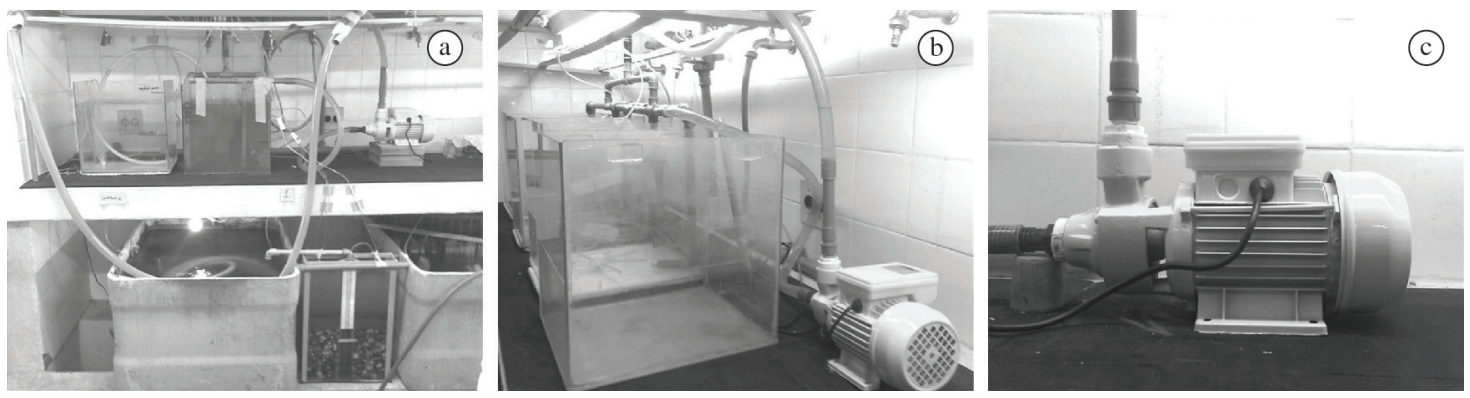

Figure 1. Mill developed for closed circulation of water and maintenance of the turbidity of the experiment: (a) hydraulic assembly; (b) detail of pipe connections; (c) pump used in the experiment. 
The abiotic components measured in field were reproduced in 10 aquariums in the experiment.

The water temperature was kept at $27^{\circ} \mathrm{C}$ and controlled by heat exchange with the cooled air of the laboratory. This was monitored with digital thermometers.

The oxygenation of the water was maintained between 9 and $10 \mathrm{mg} / \mathrm{L}$, with the help of aerators.

The electrical conductivity $(\mathrm{mS} / \mathrm{cm})$ was measured by using a conductivity meter which was monitored and calibrated in order to never exceed the minimum values of $50 \mathrm{mS} / \mathrm{cm}$ or maximum of $105 \mathrm{mS} / \mathrm{cm}$, which correspond to those measured in the field.

During the specimen selection, 167 NTU was the highest turbidity value measured, which determined the choice of a maximum turbidity limit of 250 NTU. There was a subdivision in turbidity levels, setting values to 0 , 100, 150, 200 and 250 NTU, which were obtained by means of adding sediment to the water tanks.

Turbidity conditions were constantly monitored throughout the experiment by using a turbidimeter, and, when necessary, levels were calibrated by adding sediments provided by both rivers (same granulometry) to each tank.

Two hundred molluscs collected in the Mogi-Guaçu River were randomly assigned to five tanks (40 in each) with turbidity monitored at 0,100, 150, 200 and 250 NTU. Using the same procedure, the 200 specimens collected in the Pardo River were distributed, comprising five experimental groups, with pre-determined turbidity levels.

Every 24 hours, 1 litre of a specially cultivated Chlorella $s p$ and Chlamydomonas sp microalgae culture was added to each tank and readings were taken to evaluate the stability of water conditions.

Each tank was constantly monitored and, after 120 hours, the number of dead specimens in each tank was determined.

\subsection{Choice of the model}

The basic idea was to express mortality as a function of turbidity levels and to determine whether the type of watershed could also be considered a factor of influence on mortality.

In order to analyse the risk of mortality due to turbidity at both watersheds, a multivariate logistic regression model was used (Cox, 1983).
This model was employed due to its ability to relate a dependent binary variable (in this case, death and survival categories) to other independent variables and express the proportion of deaths throughout its range $(0-100 \%)$ as a function of other independent variables. Thus, the specific watershed where $C$. fluminea was collected could be tested as a variable to analyse whether it had any significant effect on mortality.

Since a priori the intrinsic characteristics of each watershed could exert some influence on mortality of C. fluminea, each type of river was treated as a covariate.

Mortality was chosen as the dependent variable (Y), with 1 representing death and 0 , survival. The independent variables were: turbidity (expressed through its natural logarithm), and the river; with 1 and 0 representing the Mogi-Guaçu and Pardo rivers respectively.

The significance of the model in relation to the set of variables was established by using the likelihood ratio test and the contribution of each independent variable in the model was tested by using the Wald test.

After adjusting the model, confidence intervals were obtained by means of these tests, with an index of $95 \%$ for the parameters chosen and an estimate for the median.

\section{Results}

Abiotic components were monthly monitored at both collection sites, from October 2007 to October 2008 (Figure 2). During the rainy season, there was an increase not only in the electrical conductivity, but also in the turbidity levels of both rivers. However, these increases were more significant in absolute terms in the Mogi-Guaçu river.

Results of the experiment suggested that turbidity levels (Table 1) were a significant variable in explaining mortality. The mortality rate for $C$. fluminea exposed to turbidity levels of 150, 200 NTU and 250 for 120 hours was over $50 \%$ for the studied specimens.

The logistic regression model, adjusted for the two variables for the log-likelihood function, resulted in a value of -204.54 , and the $p$-value for the $\mathrm{c}^{2}(2)=116.0$ was lower than 0.0001 , confirming the significance of the model. Using the Wald test, the p-values for the coefficients of the variables were all smaller than 0.0001 , except for the variable of the river $(\mathrm{p}=0.167)$, indicating that it did not
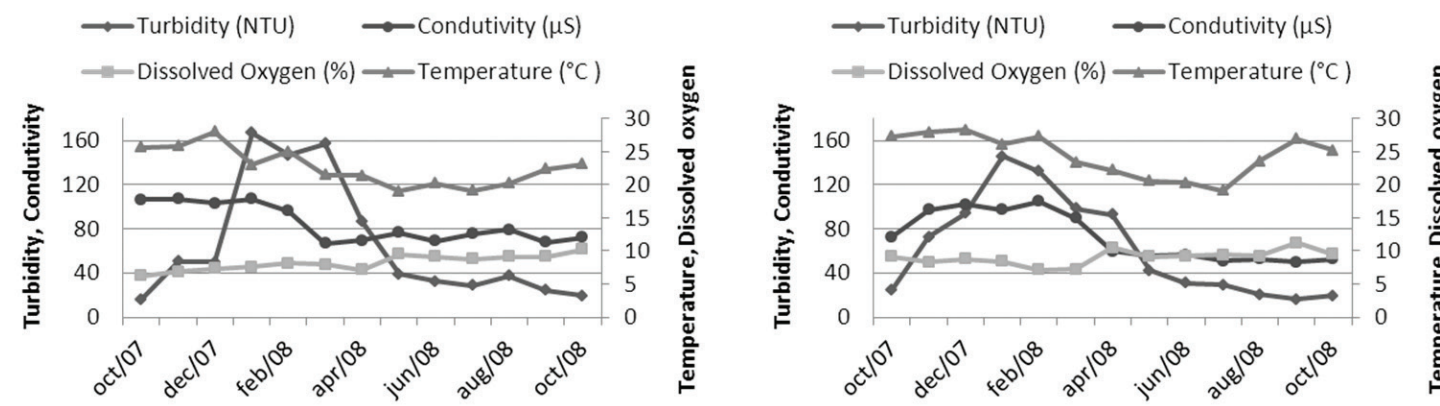

Figure 2. Graphical representation of changes in abiotic parameters, between October 2007 to October 2008: (a) river MogiGuaçu; (b) river Pardo. 
Table 1. Mortality percentage of $C$. fluminea individuals collected in river Mogi Guaçu and river Pardo, exposed to five levels of turbidity, for 120 hours $(n=400)$.

\begin{tabular}{lccccc}
\hline & \multicolumn{5}{c}{ Turbidity (NTU) } \\
\cline { 2 - 6 } & $\mathbf{0}$ & $\mathbf{1 0 0}$ & $\mathbf{1 5 0}$ & $\mathbf{2 0 0}$ & $\mathbf{2 5 0}$ \\
\hline River M. Guaçu & 0 & 20 & 55 & 60 & 65 \\
River Pardo & 0 & 25 & 62.5 & 57.5 & 70 \\
\hline
\end{tabular}

contribute significantly to the model and could therefore be deleted.

The final model, reformulated without the river variable, resulted in a value of -204.79 for the log-likelihood function, which was almost identical to that in which the river variable was included. This confirmed the watershed's lack of influence on the mortality rate of $C$. fluminea. The likelihood ratio test produced a $p$-value on the distribution $\mathrm{c}^{2}(1)$ less than 0.0001 , confirming the significance of the model. The $p$-values for the coefficients of the model resulting from the Wald test were lower than 0.0001 .

The final model was therefore as follows (Equation 1):

$\mathrm{Y}=\frac{\mathrm{e}^{-10.035+1.979 \times \ln (\text { Turb })}}{1+\mathrm{e}^{-10.035+1.979 \times \ln (\text { Turb })}}$

Figure 3 shows a graph of the model: (Figure 3)

\section{Discussion}

This study found data to support the idea that an increase in turbidity levels can be linked to higher mortality rates for the $C$. fluminea species. This helps to explain a seasonal decline in the population, especially during the period of intense hydro-meteorological events (November-January), due to the fact that both the studied watersheds have a high potential erosion risk. The sediments, although natural components of water bodies, can modify aspects of the waterway hydrology when deposited in great amounts. This is especially the case when the phenomenon of sedimentation occurs, which can reduce light penetration in the euphotic zone of the water column, drastically affecting primary production and consequently population dynamics (Neves et al., 2006).

The abiotic parameters of the watersheds for the studied period can be explained by the increase in the flow measurement, which causes the re-suspension of not only sediment particles, but also organic matter and chemical elements that had been deposited in the riverbeds. Rainfall occurring over long periods, whether continuous or briefly interrupted for short periods of time, may have resulted in the high levels of sediment recorded in these rivers, which in turn may explain the high mortality rate of specimens tested.

A 50\% mortality rate was recorded amongst specimens from both rivers after having been exposed under laboratory conditions to turbidity levels of 150 NTU or above, for 120 hours and may be similar to that observed under natural conditions, considering turbidity levels measured in both rivers during the rainy season.

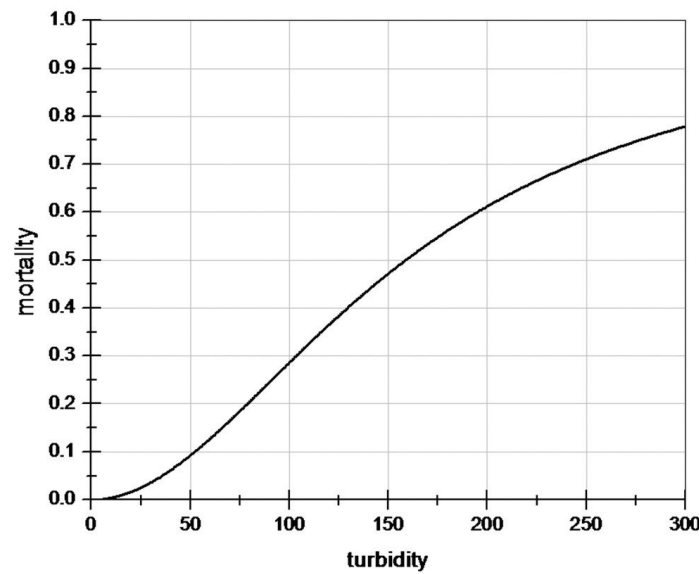

Figure 3. Modelling mortality of $C$. fluminea $(0=$ death, $1=$ mortality) as a function of turbidity (NTU).

In the Pardo river, the abiotic conditions monthly measured indicate a probable critical period for the mortality of $C$. fluminea in the month of January, when maximum turbidity levels are reached. In the Mogi Guaçu river, however, monthly readings from 2007 and 2008 indicated high levels of turbidity that persisted from January to March, suggesting a longer critical period for the survival of $C$. fluminea there.

The results of the experiments testing turbidity levels of 200 and 250 NTU were similar to those for 150 NTU conditions, and suggest that the time of exposure to the turbidity is a determining factor in the death or survival of the specimens (Neves et al., 2009). A systemic analysis of the results points to the characteristics of the watershed surrounding the main study site as having a significant effect on the composition of the $C$. fluminea community and their environment, and may have led to a decline in the local population of the species.

Frissell et al. (1986) and Davies et al. (2000) found that the degradation and fragmentation of the environment often lead to the decline of local and regional biodiversity. Poole and Downing (2004) state that, in terms of global biodiversity, freshwater bivalves are among those who suffer the most rapid decline. However, local causes are often unclear. Thus, the results of this study, when combined with Vianna's (2009) observations of mortality rates among C.fluminea at the same study sites, may indicate that the animals lose the ability to avoid adverse environmental stimuli, either by burial or horizontal 
displacement, deficiency of oxygen (Brafield, 1963), or spatial competition (Kat, 1982).

Henley et al. (2000) showed that suspended sediment and turbidity are significant contributors to the decline of populations of aquatic organisms in North America. In addition, turbidity can affect the recruitment and density of molluscs in environments affected by the entry of sediment into the system (Österling, 2010), which corroborates the results of this study. This study was particularly interested in the role of sediments as a cause of mortality of $C$. fluminea and found evidence to suggest this species' intolerance to a long exposure to high turbidity.

Finally, the use of a multivariate logistic regression model proved to be very effective and was of vital importance to assessing the risk of mortality to $C$. fluminea as a function of turbidity. This model could be useful as a preventive tool to analyse and quantify the environmental impact of turbidity and sedimentation C. fluminea's life cycle.

\section{References}

ANDERSEN, EF., 2002. Effects of land use and land cover on freshwater mussel populations in the upper Neuse River basin, NC: A GIS approach. Raleigh: North Carolina State University. Thesis.

AVELAR, WEP. and SANTOS, SCD., 1991. Functional anatomy of Castalia undosa undosa (Martens, 1827) (Bivalvia: Hyriidae). Veliger, vol. 34, no. 1, p. 21-31.

AVELAR, WEP., COSTA, AS., COLUSSO, AJ. and DAL BÓ, CMR., 1991. Sexual dimorphism in Castalia undosa undosa Martens, 1827 (Bivalvia: Hyriidae). Veliger, vol. 34, no. 2, p. 229-231.

AVELAR, WEP., 1993. Functional anatomy of Fossula fossiculifera (D’Orbigny, 1843) (Bivalvia: Mycetopodidae). American Malacological Bulletin, vol. 10, no. 2, p. 129-138.

AVELAR, WEP. and MENDONÇA, SHST., 1998. Aspects of gametogenesis of Diplodon rotundus gratus (Wagner, 1827) (Bivalvia: Hyriidae) in Brazil. American Malacological Bulletin, vol. 14, no. 2, p. 157-163.

AVELAR, WEP. and CUNHA, AD., 2009. The anatomy and functional morphology of Diplodon rhombeus fontainianus (Orbigny, 1835) (Mollusca Bivalvia, Hyriidae). Brazilian Journal of Biology, vol. 69, no. 4, p. 1153-1163. http://dx.doi.org/10.1590/ S1519-69842009000500021. PMid:19967188

BELANGER, SE., FARRIS, JL., CHERRY, DS. and CAIRNS J. Jr., 1985. Sediment preference of the freshwater Asiatic clam, Corbicula fluminea. The Nautilus, vol. 99, no. 2, p. 66-72.

BRAFIELD, AE., 1963. The effects of oxygen deficiency on the behaviour of Macoma balthica (L.). Animal Behaviour, vol. 11, no. 2-3, p. 345-346. http://dx.doi.org/10.1016/S0003-3472(63)80122-0.

COX, DR., 1983. The analysis of binary data. London: Chapman and Hall. $141 \mathrm{p}$.

CHRISTOFOLETTI, A., 1981. Geomorfologia Fluvial. São Paulo: Edgar Blucher Ltda. 313 p.

DAVIES, NM., NORRIS, RJ. and THOMS, MC., 2000. Prediction and assessment of local stream habitat features using large-scale catchment characteristics. Freshwater Biology, vol. 45, no. 3, p. 343-369. http://dx.doi.org/10.1111/j.1365-2427.2000.00625.x.
FRISSELL, CA., LISS, WJ., WARREN, CE. and HURLEY, MD., 1986. A hierarchical framework for stream habitat classification: viewing streams in a watershed context. Environmental Management, vol. 10, no. 2, p. 199-214. http://dx.doi.org/10.1007/BF01867358.

HEBLING, NJ., 1976. The functional morphology of Anodontites trapezeus (Spix) and Anodontites trapesialis (Lamarck) (Bivalvia: Mycetopodidae). Boletim de Zoologia, vol. 15, p. 265-298.

HENLEY, WF., PATTERSON, MAA., NEVES, RJ. and DENNIS LEMLY, A., 2000. Effects of sedimentation and turbidity on lotic food webs: A concise review for natural resources managers. Reviews in Fisheries Science, vol. 8, no. 2, p. 125-139. http:// dx.doi.org/10.1080/10641260091129198.

ITUARTE, CF., 1981. Primeira noticia acerca de la presencia de pelecípodos asiáticos em el área rioplatense. Neotropica, vol. 27 , no. 7 , p. $79-82$

KAT, PW., 1982. Effects of population density and substratum type on growth and migration of Elliptio complanata (Bivalvia:Unionidade). Malacological Review, vol. 15, p. 119-127.

LIAO, CM., LIN, CM., JOU, LJ. and CHIANG, KC., 2007. Linking valve closure behavior and sodium transport mechanism in freshwater clam Corbicula fluminea in response to copper. Environmental Pollution, vol. 147, no. 3, p. 656-667. http://dx.doi. org/10.1016/j.envpol.2006.09.017. PMid:17134803

MANSUR, MCD. and GARCES, LMMP., 1988. Ocorrência e densidade de Corbicula fluminea (Muller, 1774) e Neocorbicula limosa (Matton, 1811) na Estação Ecológica do Taim e áreas adjacentes, Rio Grande do Sul, Brasil (Mollusca, Bivalvia, Corbiculidae). Iheringia Série Zoologica, vol. 68, p. 95-115.

MANSUR, MCD. and CAMPOS-VELHO, NMR., 2000. The glochidium of Castalia Martensi (Ihering, 1891) (Bivalvia, Unionoida: Hyriidae). Studies on Neotropical fauna and environment, vol. 3, no. 1, p. 06-10.

MANSUR, MCD., CALLIL, CT., CARDOSO, FR. and IBARRA, JAA., 2004. Uma retrospectiva e mapeamento da invasão de espécies de Corbicula (Mollusca, Bivalvia, Veneroida, Corbiculidae) oriundas do Sudeste Asiático, na América do Sul. In SILVA, JSV. and SOUZA, RCL. (Ed.). Água de lastro e bioinvasão. Rio de Janeiro: Ed. Interciência Ltda. 224 p.

NEVES, FF., SILVA, FGB. and CRESTANA, S., 2006. Uso do modelo AVSWAT na avaliação do aporte de nitrogênio $(\mathrm{N})$ e fósforo $(\mathrm{P})$ aos mananciais de uma microbacia hidrográfica contendo atividade avícola. Engenharia Sanitária e Ambiental, vol. 11 , no. 4 , p. 311-317. http://dx.doi.org/10.1590/S141341522006000400003.

NEVES, FF., LIMA, RC. and AVELAR, WEP., 2009. Mortalidade de Corbicula fluminea (MULLER, 1774) (BIVALVIA: CORBICULIDAE) em função da exposição a diferentes condições de turbides. In Anais do VI Congresso de Meio Ambiente da $A U G M$, 2009. São Carlos: AUGM. v. 5.

ÖSTERLING, ME., ARVIDSSON, BL. and GREENBERG, LA., 2010. Habitat degradation and the decline of the threatened mussel Margaritifera margaritifera: influence of turbidity and sedimentation on the mussel and its host. Journal of Applied Ecology, vol. 47, no. 4, p. 759-768. http://dx.doi.org/10.1111/j.1365-2664.2010.01827.x.

POOLE, KE. and DOWNING, JA., 2004. Relationship of declining mussel biodiversity to stream-reach and watershed characteristics in an agricultural landscape. Journal of the North American Benthological Society, vol. 23, no. 1, p. 114-125. http://dx.doi. org/10.1899/0887-3593(2004)023<0114:RODMBT>2.0.CO;2. 
PEREDO, S. and PARADA, E., 1986. Reprodutive cycle in the freshwater mussel Diplodon chilensis chilensis (Mollusca: Bivalvia). Veliger, vol. 28, no. 4, p. 418-425.

SIMONE, LRL., 1994. Anatomical characters and systematics of Anodontites trapesialis (Lamarck, 1819) from South America (Mollusca, Bivalvia, Unionoida, Muteloidea). Studies on Neotropical Fauna and Environment, vol. 29, no. 3, p. 169-185. http://dx.doi. org/10.1080/01650529409360929.

SIMONE, LRL., 1997. Anatomy and systematics of Anodontites elongatus (Swaison) from Amazon and Paraná basins, Brazil (Mollusca, Bivalvia, Unionoida, Mycetopodidae). Revista
Brasileira de Zoologia, vol. 14, no. 4, p. 877-888. http://dx.doi. org/10.1590/S0101-81751997000400011.

VENABLES, WN. and DICHMONT, CM., 2004. A generalised linear model for catch allocation: an example from Australia's Northern Prawn Fishery. Fisheries Research, vol. 70, no. 2-3, p. 409-426. http://dx.doi.org/10.1016/j.fishres.2004.08.017.

VIANNA, MP., 2009. Aspectos da biologia de Corbicula flumínea (Müller, 1774) (Mollusca, Bivalvia, Corbiculidae) em duas bacias hidrográficas do Estado de São Paulo, Brasil. Ribeirão Preto: Universidade de São Paulo. 162 p. Tese de Doutorado na Faculdade de Filosofia, Ciências e Letras de Ribeirão Preto. 